\title{
CONCEPTUAL MODEL OF FORMATION OF PROFESSIONAL COMPETENCE OF FUTURE TEACHERS OF PHYSICAL EDUCATION IN THE FIELD OF ECOLOGICAL TOURISM
}

\author{
Andrii Konokh \\ Candidate of Sciences in Pedagogy, Senior Lecturer at the Department of Tourism \\ and Hotel and Restaurant Business, Zaporizhzhya National University, Ukraine \\ e-mail: konochaa@ukr.net,orcid.org/0000-0001-9719-0418
}

Olena Konokh

Candidate of Sciences in Physical Education and Sports, Associate Professor of Tourism and Hotel and Restaurant Business, Zaporizhzhya National University, Ukraine e-mail: konoch_a_ye@ukr.net, orcid.org/0000-0002-8970-0817

\section{Summary}

The article presents a conceptual model that provides a holistic continuous process of formation of professional competence of future teachers of physical education in the field of eco-tourism. The design of the model was based on a systematic analysis of the structure, content and consists of the following blocks: target, reflecting the social demand, it's aim, it's tasks for the formation of professional competence of future teachers of physical education in the field of eco-tourism and it's components; contents block, containing principles, organizational and pedagogical conditions for the formation of professional competence, forms and methods, which were used during the process; outcome block, which included evaluation criteria and levels of professional competence. It was found that the formation of professional competence becomes more effective due to the implementation of the following organizational and pedagogical conditions: the content focus of pedagogical education of future teachers of physical education on the formation of a stable positive motivation to master professionally notional knowledge and skills in eco-tourism and their use in professional activities; updating the content of professional training of future teachers of physical education through the implementation of specialization "Ecological and sports tourism", taking into consideration the disciplines of the social demand on strengthening and preserving the health of children and youth by means of ecological tourism in the teaching content; availability of educational and methodical support during the process of formation of professional competence; the relationship of competency, system and personal-activity approaches.

Keywords: model, teacher, components, eco-tourism, physical education.

DOI: https://doi.org/10.23856/3819

\section{Introduction}

One of the common features of modern students is a decrease in physical activity and a significant deterioration in health due to the growing popularity of attractive non-physical activities (slot machines, computer games, etc.). Studying in higher education institutions requires significant physical, intellectual and emotional efforts from students. This effect is so intense that the body's internal defenses are unable to cope with it, and the best counteraction to this is regular physical activity. Traditional forms of physical education do not always attract students to active exercise. Tourism is effective in resisting the growing hypodynamia of modern people. In recent years, eco-tourism has become very popular, which is of great importance for physical 
training, maintaining and strengthening health, aesthetic, labor, moral and patriotic education of all population segments, and especially young people mastering vital skills and abilities, in particular, based on the knowledge of the environment in natural conditions. Simple and accessible forms of organization used in eco-tourism (hiking, traveling, excursions, walks, tourist gatherings and competitions) contribute to the implementation of not only specific functions of physical education (educational, applied, sports functions) but also recreational and health-rehabilitation, provide conditions for a healthy life of the individual in society.

This necessitates the training of future physical education teachers competent in the field of tourism in higher education institutions. It is higher education institutions that are fully capable of providing a high level of teacher training for the realization of many of its functions in various spheres of human activity, especially, in ecological tourism.

Updating the content of education, on the one hand, involves focusing curricula on a competency-based approach, which is considered by scientists as one of the important conceptual principles, which determines the methodology of updating the content of education, contributes to overcoming the traditional cognitive orientations of professional education, encourages to it's content updating, methods and technologies that are transformed into the competence of the future teacher of physical education. There is a contradiction between the increased demands of society to the personality of the physical education teacher able to perform effective activities in the field of ecological tourism, and insufficient attention to the study of these issues in the professional education system, the need to direct the professional education of future physical education teachers to the formation of professional competence in the field of eco-tourism both in educational and in extracurricular processes with the predominance of the traditional approach in the organization of the educational process. The purpose of the article is to define and substantiate the conceptual model of formation of professional competence of future teachers of physical education in the field of ecological tourism

\section{Conceptual model as a social demand}

Presented problem is one of the most pressing in many fields of science, which is covered in research and publications of both foreign and domestic scientists. In the studies of professional training of future specialists in the field of tourism were engaged (Mulyk, Nosko, 2015: 217), (Fokin, 2010: 207) and others. Due attention is paid by scientists to the problems of ecological tourism as well (Dmytruk, 2009: 16), (Kosolapov, 2005: 12), etc., however, this problem continues to be insufficiently studied. This necessitates the training of future physical education teachers competent in the field of ecological tourism in higher education institutions. It is higher education institutions that are fully capable of providing a high level of teacher training for the realization of many of its functions in various spheres of human activity, especially, in ecological tourism. Updating the content of education, on the one hand, involves focusing curricula on a competency-based approach, which is considered by scientists as one of the important conceptual principles, which determines the methodology of updating the content of education, contributes to overcoming the traditional cognitive orientations of vocational education, encourages to it's content updating, methods and technologies that are transformed into the competence of the future teacher of physical education

With that been said, it should be noted that the priority of higher education institutions is to improve the content of education and organization of the process of training future physical education teachers for further professional activities, creating conditions for the development of their pedagogical skills. Each institution of higher education, creating optimal models of 
theoretical and practical training of future professionals in the field of physical education and sports, should pay attention to: revision of the content of academic disciplines in order to direct their topics to the formation of the necessary professional skills, creative thinking trait for future teachers of physical education; creation of a fundamentally new methodological support that will contribute to the disclosure of creative potential of students; the possibility of introducing various types of educational activities into the educational process. Building a model of training future teachers of physical education, we should not forget about the continuous development and constant improvement of social processes, which are reflected in the requirements for professional training. That is why such a model should focus on both traditional methods of pedagogy and modern pedagogical innovations. Within the framework of our research, a modern innovation in the process of training future physical education teachers is the creation of a model for the formation of their professional competence in the field of ecological tourism. This process is a necessary component of the study, the implementation of which is aimed at the realization of higher education institutions of an important social demand, - training of a physical education teacher who is able to professionally apply ecological tourism in educational institutions, wich results in the development of students' abilities, preventive work on their involvement in a healthy lifestyle, support of psycho-emotional state and motor activity.

Analyzing and summarizing the results of modern scientific research (Mulyk, Nosko, 2015: 217), (Fokin, 2010: 207) and others, we have developed a conceptual model (a model that is presented by a set of concepts and connections between them, which determine the semantic structure of the modeled object and process) of professional competence of future teachers of physical education in the field of ecological tourism as a system of interconnected, interdependent integral elements, united by a common goal and result-oriented, - professional competence in a determined type of activity. The basis for building a conceptual model was a social demand to introduce the basics of eco-tourism for the process of training future teachers of physical education, and the leading idea is that the formation of professional competence in the field of eco-tourism should be cross-cutting, to take place during the whole period of study and to combine theoretical and practical training, as well as extracurricular activities of students.

The developed conceptual model of formation of professional competence of future teachers of physical education in the field of ecological tourism is the united system, consisting, according to the classical structure of activity, of three main blocks: target, outcome and results blocks, structural elements of which perform their own functions and are closely interconnected with each other. The basis for building the conceptual model is the social demand for physical education teachers who are able to strengthen and preserve the health of children and youth through eco-tourism.

The main structural elements of the developed conceptual model are the components of professional competence, purpose, tasks, principles, organizational and pedagogical conditions, methods and forms, which provide the formation of professional competence of future teachers of physical education in the field of eco-tourism, as well as criteria and indicators by which the result is evaluated - the professional competence of future teachers of physical education in the field of eco-tourism.

\section{The target block of the model}

The content of the target block of the conceptual model is determined by the components of professional competence, the purpose of the social demand of modern society to form, strengthen and preserve the health of children and youth through eco-tourism and tasks that are 
the basis for projecting expected results In the formation of professional competence of future teachers of physical education in the field of ecological tourism, we have identified the following components: personal, cognitive, praxeological, reflexive.

The personal component of professional competence involved the formation of students' understanding of the importance of the social order for a physical education teacher capable of forming, strengthening and maintaining the health of children and youth through eco-tourism, as well as motivation for future professional activity; cognitive - the acquisition by future teachers of a certain amount of knowledge and mastery of skills in the organization of ecological tourism; praxeological - an attempt to embody theoretical knowledge in practice; reflexive - the organization of ecological tourism taking into consideration the acquired theoretical and practical knowledge, evaluation of performance.

Thus, the purpose of professional training of future teachers of physical education in higher education, as indicated in the developed conceptual model, is the formation of their professional competence in the field of eco-tourism.

Based on the purpose of professional training of future teachers of physical education and the structure of their professional competence in the field of eco-tourism, the following tasks are defined:

1) formation of a positive attitude to ecological tourism and the need for its use in the professional sphere, which means the formation of the personal component of professional competence;

2) ensuring the mastery by future specialists of a set of necessary professional knowledge on the organization of ecological tourism, which means the formation of the cognitive component of professional competence;

3) providing mastery of skills in the organization of ecological tourism in professional activities is the formation of the praxeological component of professional competence;

4) development of professional qualities (first of all, empathy, creativity, reflection, self-organization) that determine the success of tourism activities, which is the formation of a reflective component of professional competence.

\section{Content block of the model}

The content block of the conceptual model of formation of professional competence of future physical education teachers in the field of ecological tourism is determined by a set of interconnected elements that ensure the integrity of the training process and allow to achieve the goal.

The specifics of the formation of professional competence of future teachers of physical education in the field of eco-tourism, led to the choice of organizational and pedagogical conditions.

The first condition - the focus of the content of pedagogical education of future teachers of physical education on the formation of a stable positive motivation to master professionally significant knowledge and skills in eco-tourism and their use in professional activities - was performed by implementing an integration approach to the conduction of the content of education at the bachelor's level.

The choice of a set of disciplines had a positive impact on the formation of professional competence of future teachers of physical education in the field of eco-tourism and provided a solid foundation for increasing motivation and implementation of knowledge, skills and abilities in professional activities. The second condition is the improvement of the content 
of professional training of future physical education teachers by introducing the specialization "Ecological and sports tourism" in the master's program.

The content of disciplines takes into consideration the social demand to strengthen and preserve the health of children and youth through eco-tourism, which contributes to the expansion of scientific ideas of students about the peculiarities of the content of the production functions of this type of tourism, tasks of professional activity and professional competence of future physical education teachers. The content of professional training at the educational level "Master's degree" is aimed at forming the professional competence of future teachers of higher education institutions.

The third condition is educational and methodological support for the formation of professional competence of future teachers of physical education in the field of ecological tourism. It was planned to increase the level of knowledge in the field of ecological tourism. The fourth condition - the use of the relationship of competency, system and personal approaches in the study of professional disciplines. The relationship was ensured by the integration of approaches in the formation of professional competence of future teachers of physical education in the field of eco-tourism. The key in this complex is the competence approach, the implementation of which took place during the process of studying by students of the modules of disciplines of the professional cycle. The system approach ensured consistency of the formation of professional competence of future teachers (professional training from solving simple problems to more complex ones, from studying theoretical issues to their testing in practice, especially during internships, participation in group work, etc.). It was found that the complex of these approaches has a positive effect on the effectiveness of the formation of professional competence of future teachers of physical education in the field of ecological tourism.

\section{The outcome block of the model}

The outcome block of the conceptual reflects the criteria and indicators, due to the complex diagnostics of which the level of professional competence of future teachers of physical education in the field of ecological tourism is determined.

The level of formation of professional competence of future teachers of physical education in the field of ecological tourism, which is the result of training students in higher education is determined by the complex indicator according to four criteria - motivational-value, information-cognitive, operational-activity, evaluation-corrective, on four levels (low, average, sufficient, high).

\section{Conclusion}

The presented author's conceptual model provides a holistic continuous process of formation of professional competence of future teachers of physical education in the field of ecological tourism, which includes three interconnected blocks providing the optimal way to achieve the educational goal: the target block, which reflects the social demand of society, the purpose, the task of forming the professional competence of future teachers of physical education in the field of eco-tourism and its components, reflects the purpose and objectives of the training process; the content block, which contains organizational and pedagogical conditions for the formation of professional competence of future teachers of physical education in the field of eco-tourism, forms and methods used in this process, determines the content of training, its principles, organizational and pedagogical conditions, forms and methods; the outcome block 
visualizes criteria and indicators of efficiency of formative actions, adequacy of the received results to the set purpose. Execution of the constructed conceptual model, realization of certain organizational and pedagogical conditions in the system of higher education will provide effective formation of professional competence of future teachers of physical education in the field of ecological tourism. Approaches to the content of the professional block of disciplines in accordance with changes in the scope of their study need further updating, provided by the correction of state standards in accordance with the requirements of the new Law of Ukraine "About Higher Education" and the introduction of new information technologies in the training of future teachers of physical education.

\section{References}

Dmitruk O. Yu., Dmitruk S. V. (2009). EKOturyzm: navch. posib. [ECOTourism: textbook]. Kyiv: Alterpress, 358 p. [in Ukrainian].

Kosolapov A. B. (2005). Teoryia y praktyka ekolohycheskoho turyzma: ucheb. posob. [Theory and practice of ecological tourism]. Moscow, 240 p. [in Russian].

Mulyk K. V., Nosko M. O. (2015). Dyferentsiiovanyi pidkhid do pidhotovky fakhivtsiv zi sportyvno-ozdorovchoho turyzmu dlia roboty z ditmy, pidlitkamy ta studentskoiu moloddiu [Differentiated approach to the training of specialists in sports and health tourism to work with children, adolescents and students]. Bulletin of Chernihiv National Pedagogical University. Series: Pedagogical sciences. Physical education and sports, Nr 129 (2), P. 217-222. [in Ukrainian].

Fokin S. P. Turyzmolohichni aspekty sportyvnoho turyzmu [Tourism aspects of sports tourism]. Scientific Bulletin of the Institute of International Relations of NAU: Coll. Science. Art. Kyiv: Nat. aviation. University «NAU-print», voll., Nr 1, 148 p. [in Ukrainian]. 